\title{
MgS04 And Slow Stroke Back Massage Therapy On Blood Pressure of Severe Pre Eclampsia Pregnant Women
}

\author{
Ulin Nikmah'1, Machmudah² \\ ${ }^{1}$ Roemani Muhammadiyah Hospital of Semarang \\ 2 University of Muhamadiyah Semarang
}

\section{Article Info}

\section{Article History:}

Accepted May 7th, 2019

\section{Key words:}

Blood Pressure;

Preeclampsia; MgSO4; SSBM

\section{INTRODUCTION}

The number of pregnant women at Roemani Muhammadiyah Hospital Semarang in 2017 was 1,589 people, of which 94 were pregnant women with preeclampsia, if at an average of $7.33 \%$ or as many as 7 pregnant women with preeclampsia each month. Whereas in 2018, in 8 months from January to August 2018 there were 1048 pregnant women, in which pregnant women with preeclampsia reached 82 people, not even 12 months there had been an increase in pregnant women with preeclampsia, if on average every month pregnant women with preeclampsia as much as $10.25 \%$ or as many as 10 people every month.

Preeclampsia (Toxemia Gravidarum) is a condition that occurs in pregnant women, maternity and childbirth usually occurs in the second trimester until the first week after labor with symptoms of hypertension,

Corresponding author:

Ulin Nikmah 
edema and proteinuria. ${ }^{1}$ Preeclampsia is a dangerous complication for pregnant women and their fetuses, this can cause damage to body organs such as heart failure, kidney failure, liver function disorders, blood clotting disorders, HELLP syndrome, death for the mother and fetus, if not treated immediately properly and correctly. ${ }^{1,2}$

General management of severe preeclampsia by paying attention to the airway, breathing, and circulation if there is a seizure. Then administer $\mathrm{MgSO}_{4}$ intravenously to mothers as prevention of seizures. $^{3}$ The mechanism of action of MgSO4 is not fully understood but, it is thought to cause dilatation of the cerebral arteries so as to reduce cerebral ischemic (ischemia in the brain). Magnesium blocks calcium receptors by inhibiting N-MethylD-aspartate receptors in the brain. Magnesium also produces peripheral (especially arterioles) vasodilation which reduces blood pressure. MgSO4 plays a role in blocking calcium entry to the synaptic end so that it will change the neuro muscular transmission. This transmission is influenced by the presynaptic greater as well as the post synaptic effect. Presynaptic acetylcholine release is also reduced so that it will alter neuromuscular transmission. The precise mechanism of action for the tocolytic effects of $\mathrm{MgSO} 4$ is not clearly defined, but may be related to the action of magnesium as a calcium inhibitor which inhibits muscle contraction so that no seizures occur. ${ }^{3,4}$

Side effects of administration of MgSO4 in pregnant women with pre-eclampsia are usually associated with hypermagnesemia (excess magnesium levels), such as nausea, vomiting, thirst, flushing the skin, sleepiness, confusion, loss of tendon reflexes, muscle weakness, hypotension, arrhythmia, respiratory depression, and coma. The observation was carried out after the administration of $\mathrm{MgSO}_{4}$ by examining blood pressure, frequency of pulse and respiration, patellar reflexes and urine count. This aims to determine the progress of the administration of $\mathrm{MgSO} 4$ and if the results of the examination are less than normal, MgSO4 will be stopped.

How to reduce the risk that occurs in pregnant women with severe preeclampsia should be given independent therapy to help decrease blood pressure during pregnancy in a natural way and can be done easily. One care that can reduce high blood pressure is to give a gentle massage to the mother's back called slow stroke back massage. One factor that makes the occurrence of preeclampsia in pregnant women is a change in blood pressure during pregnancy that has increased so that one intervention that is nonpharmacological to help reduce pressure easily and cheaply is by slow stroke back massage. ${ }^{5,6}$

Slow stroke back massage is a manipulation therapy with gentle massage on the tissue that aims to provide effects on physiology, especially in the vascular, muscular and nervous systems of the body. Slow stroke back massage not only provides overall relaxation but also benefits health such as smoothing blood circulation, lowering blood pressure, reducing pain response and improving sleep quality. ${ }^{7}$

From the results of a brief interview with nurses in the Ayyub 1 room, Roemani Muhammadiyah Hospital, Semarang, information was obtained that a nurse must specifically monitor the physiological response of pregnant women after administration of MgSO4. Because it turns out the effects of MgSO4 on pregnant women can cause hypotension, also decrease contractions to arrhythmias, respiratory depression to the more severe, namely coma. Whereas in the fetus the effects of $\mathrm{MgSO} 4$ can cause a decrease in FHR so that it can cause death in the fetus. Effects on giving birth after giving $\mathrm{MgSO} 4$ can cause postpartum bleeding. And still, according to one nurse in theAyyub 1 
room, a massage performed on pregnant women with severe preeclampsia can help mothers relax so that it affects the decrease in blood pressure. Based on these descriptions, researchers are interested in conducting research with the title "The Effect of MgSO4 Therapy and Slow Stroke Back Massage on Blood Pressure in Pregnant Women With Severe Preeclampsia".

\section{METHODS}

The type of research used was quasiexperimental or quasi-experimental using a form of pre-post treatment planning divided into two groups (two-group pretest - post-test design). This study aims to compare the blood pressure of pregnant women with severe preeclampsia before and after MgSO4 therapy and compare the blood pressure of pregnant women before and after slow stroke back massage.

In this study, the population is pregnant women with severe preeclampsia at Roemani Muhammadiyah Hospital Semarang from January to August 2018, namely 82 pregnant women with severe preeclampsia. The sampling technique used in this study is Purposive Sampling so that the number of samples is 32 respondents, the sample is divided into two different groups. The research was conducted at Roemani Muhammadiyah Hospital Semarang in January - March 2019 data collection tools with observation sheets, data were analyzed by univariate and bivariate (Wilcoxon Match Pairet Test).

\section{RESULTS}

The characteristics of the respondents were 32 years old, the majority of respondents were $50 \%$ private workers (8 respondents in the group given $\mathrm{MgSO} 4$ and SSBM), the average gestational age of the respondents was 37 weeks, the respondents' gravida status as much as the second pregnancy was 15 respondent (46.9\%).
Table 1

Characteristics of respondents

\begin{tabular}{|c|c|c|c|}
\hline \multicolumn{2}{|c|}{ Indicators } & MgSO4 & $\begin{array}{l}\mathrm{MgSO} 4 \\
+\mathrm{SSBM}\end{array}$ \\
\hline Age, mean ( & & $\begin{array}{c}31,87 \\
(4,334)\end{array}$ & $\begin{array}{c}33,69 \\
(4,813)\end{array}$ \\
\hline $\begin{array}{l}\text { Gestational } \\
\text { mean (SD) }\end{array}$ & Age, & $\begin{array}{c}36,938 \\
(1,8062)\end{array}$ & $\begin{array}{c}37,562 \\
(2,3656)\end{array}$ \\
\hline
\end{tabular}

Based on table 1, it can be seen that the youngest age in the group of pregnant women with severe preeclampsia who received MgSO4 therapy was 24 years, and the oldest was 39 years. The average age is 31.87 , with a standard deviation of \pm 4.334 . The youngest age in the group of pregnant women treated with MgSO4 and Slow Stroke back Massage was 26 years, and the oldest was 41 years. The average age is 33.69 with a standard deviation of \pm 4.813 . Based on this table can be seen that gestational age in the group that received the lowest MgSO4 therapy was 33 weeks and the highest was 39 weeks. The average age is 36.938 with a standard deviation of 1.8062. The gestational age in the group treated with MgSO4 and the lowest stroke back massage was 31 weeks and the highest was 40 weeks. The average age is 37.562 with a standard deviation of 2.3656 .

Table 2

The systole and diastolic blood pressure before and after receiving the therapy

\begin{tabular}{|c|c|c|}
\hline Indicators & $\mathrm{MgSO} 4$ & $\begin{array}{l}\mathrm{MgSO} 4 \\
+\mathrm{SSBM}\end{array}$ \\
\hline $\begin{array}{l}\text { Systolic blood pressure } \\
\text { before receiving MgSO4 } \\
\text { therapy, mean (SD) }\end{array}$ & $\begin{array}{c}168,63 \\
(11,865)\end{array}$ & $\begin{array}{l}151,94 \\
(6,082)\end{array}$ \\
\hline $\begin{array}{l}\text { Systolic blood pressure } \\
\text { after receiving MgSO } 4 \\
\text { therapy, mean (SD) }\end{array}$ & $\begin{array}{c}153,75 \\
(16,619)\end{array}$ & $\begin{array}{c}141,87 \\
(3,862)\end{array}$ \\
\hline $\mathrm{p}$ & 0,005 & 0,003 \\
\hline $\begin{array}{l}\text { Diastolic blood } \\
\text { pressure before getting } \\
\text { MgSO4 therapy, mean } \\
\text { (SD) }\end{array}$ & $\begin{array}{c}104,44 \\
(16,496)\end{array}$ & $\begin{array}{c}94,81 \\
(6,901)\end{array}$ \\
\hline $\begin{array}{l}\text { Diastole blood pressure } \\
\text { after receiving MgSO } 4 \\
\text { therapy, mean (SD) }\end{array}$ & $\begin{array}{c}91,88 \\
(8,326)\end{array}$ & $\begin{array}{c}87,00 \\
(6,633)\end{array}$ \\
\hline $\mathrm{p}$ & 0,001 & 0,001 \\
\hline
\end{tabular}

Based on table 2, It can be seen that the systole blood pressure before the lowest MgSO4 value is $160 \mathrm{mmHg}$ and the highest 
value is $200 \mathrm{mmHg}$. The mean systole blood pressure before getting $\mathrm{MgSO} 4$ therapy was 168.63 with a standard deviation of 11.865. Diastole blood pressure before getting MgSO4 therapy the lowest value is $90 \mathrm{mmHg}$ and the highest value is $150 \mathrm{mmHg}$. The mean diastolic blood pressure before getting $\mathrm{MgSO} 4$ therapy was 104.44 with a standard deviation of 16.496. Based on the table, it can be seen that the systole blood pressure after getting MgSO4 therapy the lowest value is $139 \mathrm{mmHg}$ and the highest value is $190 \mathrm{mmHg}$. The mean systole blood pressure after getting MgSO4 therapy was 153.75 with a standard deviation of 16.619 . Diastole blood pressure after getting $\mathrm{MgSO} 4$ therapy the lowest value is 80 $\mathrm{mmHg}$ and the highest value is $110 \mathrm{mmHg}$. The mean diastolic blood pressure after obtaining MgSO4 therapy was 91.88 with a standard deviation of 8.326. Result of the research was shown that systolic blood pressure in pregnant women with severe preeclampsia before and after $\mathrm{MgSO} 4$ therapy is p-value $0.005(<0.05)$, so it is normally distributed ie there is influence of changes in systole in pregnant women with severe preeclampsia before and after $\mathrm{MgSO} 4$ and there is an effect of changes in diastolic blood pressure in pregnant women with severe preeclampsia before and after MgSO4 therapy (p-value 0.001).

Based on table 4.4 It can be seen that the systole blood pressure before getting MgSO4 therapy and slow stroke back massage the lowest value is $140 \mathrm{mmHg}$ and the highest value is $161 \mathrm{mmHg}$. The mean systole blood pressure before getting MgSO4 therapy was 151.94 with a standard deviation of 6.082. Diastole blood pressure before getting MgSO4 therapy the lowest value was $88 \mathrm{mmHg}$ and the highest value was $110 \mathrm{mmHg}$. The mean diastolic blood pressure before getting $\mathrm{MgSO} 4$ therapy was 94.81 with a standard deviation of 6.901.

Based on table 2, It can be seen that systole blood pressure after getting MgSO4 therapy and slow stroke back massage the lowest value is $137 \mathrm{mmHg}$ and the highest value is $150 \mathrm{mmHg}$. The mean systole blood pressure after receiving $\mathrm{MgSO} 4$ therapy was 141.87 with a standard deviation of 3.862. Diastole blood pressure after getting $\mathrm{MgSO} 4$ therapy the lowest value was $74 \mathrm{mmHg}$ and the highest value was $100 \mathrm{mmHg}$. The mean diastole blood pressure after getting MgSO4 therapy was 87.00 with a standard deviation of 6.633 .

Based on Table 4.4 , it can be seen that Pvalue $=0.001$, this shows that there is a change in the physiological response of systolic blood pressure in pregnant women with severe preeclampsia before and after MgSO4 therapy and slow stroke back massage and there is a change in the physiological response of systolic blood pressure in pregnant women with severe preeclampsia before and after $\mathrm{MgSO} 4$ therapy and slow stroke back massage ( $p$ value 0.001 ).

\section{DISCUSSION}

Research conducted on 32 respondents after therapy either given $\mathrm{MgSO} 4$ or given $\mathrm{MgSO} 4$ and Slow stroke Back Massage showed a significant change in blood pressure reduction in both systole and diastole. The effect of therapy can be proven by Wilcoxon bivariate analysis. $\mathrm{P}$ value is less than 0.005 .

The mechanism of slow stroke back massage is in the form of a long and soft swab that produces a relaxing effect in the body which causes a decrease in heart rate and blood pressure. Relaxation is beneficial in reducing stress levels and vasodilation of blood vessels. The mechanism of slow stroke back massage increases relaxation by decreasing sympathetic nerve activity and increasing parasympathetic nerves which causes the release of endorphins which make blood vessels vasodilatory.8,9 The mechanism of therapy for $\mathrm{MgSO} 4$ and slow stroke back massage both work as vasodilators to help reduce blood pressure 
in pregnant women with severe preeclampsia. ${ }^{10}$

MgSO4 is an important mineral in the human body that is mostly in the bone. Metabolism and distribution of other minerals in the body such as calcium and potassium are often associated with magnesium levels. $\mathrm{MgSO} 4$ used as a vasodilator in preeclampsia and eclampsia is also indicated for replacement therapy in magnesium deficiency with signs of muscle spasms. The mechanism of action for the tocolytic effect of MgSO4 is not clearly known but is used to reduce PE and SE development where after administration of MgSO4 intravenously in women with severe preeclampsia shows a strong potential to prevent the onset of eclampsia. ${ }^{11}$

This research was supported by another research, where the results showed that blood pressure decreased after slow stroke back massage, with the results that there was a decrease in systolic blood pressure decrease in diastolic blood pressure. ${ }^{5}$

\section{CONCLUSION}

Besides primigravida who is at risk for severe preeclampsia also in pregnancies with grand multipara, as many as 3 respondents (18.8\%) pregnant women with severe preeclampsia who received MgSO4 therapy and slow stroke back massage because pregnancy more than 3 times will cause excessive uterine stretching so that cause excessive ischemia and affect the occurrence of severe preeclampsia.

The influence of blood pressure on pregnant women with severe preeclampsia obtained the results of the study which showed P-value $=0.001$ where $\mathrm{p}$-value $<0.05$, so this shows that there are differences in the physiological response of blood pressure in pregnant women with severe preeclampsia before and after received MgSO4 therapy. While the physical response of blood pressure in pregnant women with severe preeclampsia was obtained by the results of the study which showed that P-value $=0.001$, this indicates that there are differences in the physiological response of systolic blood pressure in pregnant women with severe preeclampsia before and after $\mathrm{MgSO} 4$ therapy and slow stroke back massage.

\section{CONFLICTS OF INTEREST}

The author declares that none of them had any conflict of interests.

\section{REFERENCES}

1. Shah S, Gupta A. Hypertensive Disorders of Pregnancy. Cardiol Clin [Internet]. 2019 May [cited 2019 Jun 22];0(0). Available from: https://linkinghub.elsevier.com/retrieve/pii/S 0733865119300347

2. Lowdermilk DL, Perry SE, Cashion K, Alden KR, Olshansky EF. Maternity \& women's health care. 11th editions. St. Louis, MO: Elsevier; 2016. xxiv, 973 pages.

3. Graham NM, Gimovsky AC, Roman A, Berghella V. Blood loss at cesarean delivery in women on magnesium sulfate for preeclampsia. J Matern Neonatal Med [Internet]. 2015 Aug 26 [cited 2019 Jun 22];1-5. Available from: http://www.tandfonline.com/doi/full/10.310 9/14767058.2015.1064107

4. Kawasaki K, Kondoh E, Chigusa Y, Kawamura Y, Mogami H, Takeda S, et al. Metabolomic Profiles of Placenta in Preeclampsia. Hypertension [Internet]. 2019 Mar [cited 2019 Jun 22];73(3):671-9. Available from: https://www.ahajournals.org/doi/10.1161/H YPERTENSIONAHA.118.12389

5. Aryani AN, Wahyuni S. Pengaruh Pemberian Back Exercise dan Slow-Stroke Back Massage Terhadap Penurunan Nyeri Haid Primer [Internet]. Universitas Muhammadiyah Surakarta; 2016. Available from: http://eprints.ums.ac.id/47832/

6. Mohaddes F, Ehsanpour NG, Ghezeljeh TN. The effect of slow-stroke back massage on anxiety in female patients with heart failure. Bali Med J [Internet]. 2018 Aug 5 [cited 2019 Jun 22];7(2):475. Available from: https://www.balimedicaljournal.org/index.ph 
$\mathrm{p} / \mathrm{bmj} /$ article/view/899

7. Dewi AP. Efektifitas Kombinasi Terapi Slow Stroke Back Massage Dan Akupresur Terhadap Penurunan Tekanan Darah Pada Penderita Hipertensi. J Online Mhs Bid Ilmu Keperawatan. 2015;2(2):1299-307.

8. Kozier B. Fundamentals of Nursing: Concepts, Process, and Practice [Internet]. Pearson Education, Limited; 2011. Available from: https://books.google.co.id/books?id=nBZFNA EACAAJ

9. Potter, P. A., Perry, A. G., Stockert, P., \& Hall A. Fundamentals of Nursing-E-Book. Elsevier H. 2011.
10. Gray C, Vickers MH, Dyson RM, Reynolds CM, Berry MJ. Magnesium sulfate has sex-specific, dose-dependent vasodilator effects on preterm placental vessels. Biol Sex Differ [Internet]. 2015 Dec 4 [cited 2019 Jun 22];6(1):22. Available from: http://www.bsdjournal.com/content/6/1/22

11. Saha PK, Kaur J, Goel P, Kataria shalija, Tandon $\mathrm{R}$, Saha L. Safety and efficacy of low dose intramuscular magnesium sulphate (MgSO4) compared to intravenous regimen for treatment of eclampsia. J Obstet Gynaecol Res [Internet]. 2017 Oct 1 [cited 2019 Jun 22];43(10):1543-9. Available from: http://doi.wiley.com/10.1111/jog.13424 